\title{
Effects of bromopride on the healing of left colonic anastomoses in rats with induced abdominal sepsis ${ }^{1}$
}

\author{
Efeitos da bromoprida na cicatrização de anastomoses no cólon esquerdo de ratos sob sepse \\ abdominal induzida
}

\author{
Silvana Marques e Silva ${ }^{\mathrm{I}}$, Fabiana Pirani Carneiro ${ }^{\mathrm{II}}$, Paulo Gonçalves de Oliveira ${ }^{\mathrm{III}}$, Pedro Henrique Alves de Morais ${ }^{\mathrm{IV}}$, Naiara \\ Galvão da Silva ${ }^{I v}$, João Batista de Sousav
}

IFellow, PhD degree, Postgraduate Program in Medical Sciences, Medical School, UnB, Brasilia-DF, Brazil. Responsible for intellectual and scientific content of the study, designed the protocol, involved with technical procedures, acquisition and interpretation of data, statistical analysis, critical revision and manuscript writing.

IIPhD, Associate Professor of Pathology, Medical School, UnB, Brasilia-DF, Brazil. Macroscopic and histopathological examinations, interpretation of data and critical revision.

IIIPhD, Associate Professor, Surgical Clinics, Medical School, UnB, Brasilia-DF, Brazil. Statistical analysis, interpretation of data and critical revision. ${ }^{\mathrm{IV}}$ Graduate student, Medical School, UnB, Brasilia-DF, Brazil. Involved with technical procedures, acquisition and interpretation of data, statistical analysis.

${ }^{\mathrm{v}} \mathrm{PhD}$, Associate Professor, Surgical Clinics, Medical School, UnB, Brasilia-DF, Brazil. Responsible for intellectual and scientific content of the study, designed the protocol, involved with technical procedures, interpretation of data, critical revision and manuscript writing.

\section{ABSTRACT}

PURPOSE: To evaluate the effects of bromopride on the healing of left colonic anastomoses in rats with induced abdominal sepsis. METHODS: Forty rats were divided into two groups to receive either bromopride (experimental group- E) or saline (control groupC). Each group was divided into subgroups of ten animals each to be euthanized on third (E3 and C3) or seventh day (E7 and C7) after surgery. Sepsis was induced by cecal ligation and puncture. The rats underwent segmental left colon resection and end-to-end anastomosis. Adhesion formation, tensile strength and hydroxyproline concentration were assessed. Histomorphometry of collagen and histopathological analysis were also performed.

RESULTS: On postoperative third day, anastomoses in bromopride-treated animals showed lower tensile strength ( $\mathrm{p}=0.02)$ and greater reduction in hydroxyproline concentration $(p=0.04)$ than in control animals. There was no statistical difference in these parameters on seventh day, and the remaining parameters were similar across subgroups. Collagen content was also similar across subgroups.

CONCLUSION: In the presence of abdominal sepsis, the administration of bromopride was associated with decreased tensile strength and hydroxyproline concentration in left colonic anastomoses in rats three days after surgery.

Key words: Anastomosis, Surgical. Colon. Sepsis. Grastrointestinal Motility. Tissue Adhesions. Rats.

\section{RESUMO}

OBJETIVO: Avaliar os efeitos da bromoprida sobre a cicatrização de anastomoses de cólon esquerdo de ratos na presença de sepse abdominal.

MÉTODOS: Quarenta ratos distribuídos em grupos contendo 20 animais para administração de bromoprida ou salina. Cada grupo foi dividido em subgrupos contendo dez animais, para eutanásia no terceiro ou no sétimo dia de pós-operatório. A indução da sepse foi realizada pelo método de ligadura e punção do ceco. Foi realizada ressecção de um segmento do cólon esquerdo e anastomose términoterminal. À re-laparotomia, foi avaliada a quantidade total de aderências e removido um segmento colônico contendo a anastomose para análise histopatológica, força de ruptura, concentração de hidroxiprolina e histomorfometria do colágeno.

RESULTADOS: No $3^{\circ} \mathrm{DPO}$, as anastomoses dos animais tratados com bromoprida apresentaram menor força de ruptura $(\mathrm{p}=0,02$ ) e maior redução da concentração de hidroxiprolina $(\mathrm{p}=0,04)$ que os animais controle. Não houve diferença estatística quanto a estes parâmetros no $7^{\circ} \mathrm{DPO}$. O conteúdo de colágeno foi semelhante entre os subgrupos.

CONCLUSÃO: Na presença de sepse abdominal, o uso da bromoprida esteve associado à diminuição da força de ruptura e da concentração de hidroxiprolina das anastomoses do cólon esquerdo de ratos no $3^{\circ} \mathrm{DPO}$.

Descritores: Anastomose Cirúrgica. Cólon. Sepse. Motilidade Gastrointestinal. Aderências Teciduais. Ratos. 


\section{Introduction}

Several factors may affect the healing of intestinal anastomoses, including intraperitoneal infection and drug use $\mathrm{e}^{1-3}$.

One of the most frequently used models to study the pathophysiology of abdominal sepsis and its systemic consequences is the cecal ligation and puncture (CLP) model. This model is associated with polymicrobial sepsis and bacteremia and has the advantage of combining tissue injury with the ability to modulate the degree of bacterial contamination and mortality 4 .

Bromopride (4-amino-5-bromo-N-[2-(diethylamino) ethyl]-2-methoxybenzamide) is a prokinetic agent that has antiemetic action and the ability to stimulate gastrointestinal motility. This drug is often used in the treatment of paralytic ileus and control of postoperative nausea and vomiting.

In a previous study, we found that administration of bromopride in the absence of sepsis was associated with decreased tensile strength of left colonic anastomoses in rats three days after surgery ${ }^{5}$. A search of the literature returned no studies specifically related to the influence of bromopride on the healing of intestinal anastomoses in the presence of infection.

This study aimed to evaluate the effects of bromopride on the healing of left colonic anastomoses in rats with induced abdominal sepsis.

\section{Methods}

The study was performed at the Laboratory of Experimental Surgery, Department of Clinical Surgery, Medical School, University of Brasilia (UnB), Brazil. All experiments and procedures were approved by the Institutional Animal Care and Use Committee of UnB Institute of Biological Sciences (protocol no. 67336/2009) and conformed to the Brazilian guidelines involving animals in research.

A total of 40 healthy male Wistar rats (Rattus norvergicus), with initial body weight of 350 to $575 \mathrm{~g}$ and 90 to 120 days of age, were used in the study. For two weeks preoperatively, the animals were housed in groups of five in home cages, maintained on a 12:12 light-dark cycle, and had ad libitum access to water and standard chow. There was no preoperative fasting.

The rats were randomly divided into two groups of 20 animals each to receive either bromopride (experimental groupE) or saline (control group- C) postoperatively. Each group was then divided into subgroups of 10 animals each to be euthanized on third (E3 and C3) or seventh day (E7 and C7) after surgery (Figure 1).

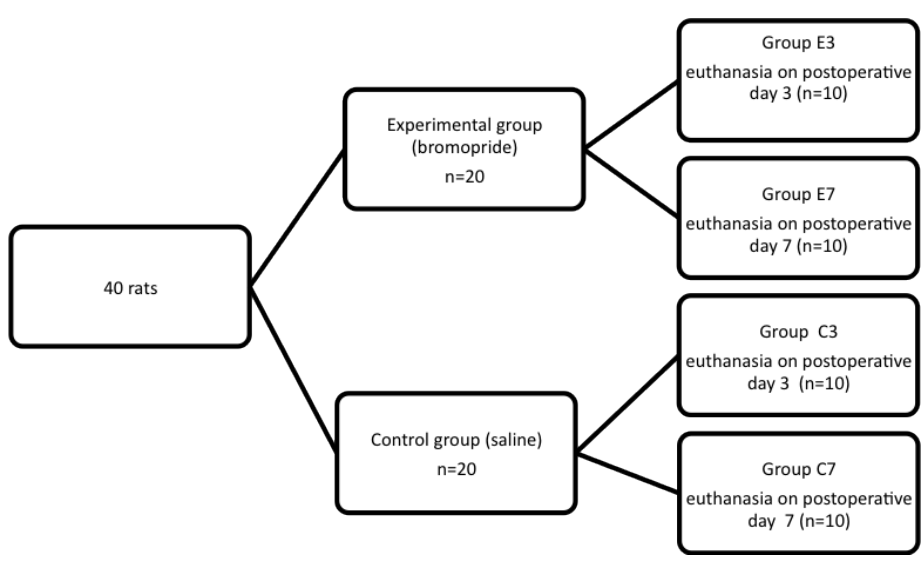

FIGURE 1 - Allocation of animals into groups.

The animals were anesthetized with xylazine hydrochloride $(10 \mathrm{mg} / \mathrm{kg})$ and ketamine hydrochloride $(75 \mathrm{mg} / \mathrm{kg})$ intramuscularly. All surgical procedures were performed by one surgeon.

Laparotomy consisted of a 4.0-cm midline incision of the abdominal wall, starting $1.0 \mathrm{~cm}$ above the external genitalia of animals. The distal colon was exposed, and $0.5 \mathrm{~cm}$ of the left colon was resected 2.5 to $3.0 \mathrm{~cm}$ above the peritoneal reflection, followed by end-to-end anastomosis of the segment, in a single transmural layer, using running 6-0 polypropylene suture and a blunted needle. CLP-induced abdominal sepsis was performed as described by Rittirsch et al. ${ }^{6}$. After anastomosis, 50\% of exposed cecum was ligated with 3-0 silk suture $\left(\right.$ Shalon $\left.^{\circledR}\right)$. Then, 10 random perforations were made at the end of the cecum distal to the ligation site using a $40 \times 13 \mathrm{~mm}$ venipuncture needle, and a small amount of feces was extruded. The abdominal wall was closed in two layers with running 3-0 silk suture.

After the procedure, bromopride (total daily dose of 1 $\mathrm{mg} / 100 \mathrm{mg}$ of body weight) was administered subcutaneously to animals in the experimental subgroups every $12 \mathrm{~h}$ until the day of euthanasia. Control animals received identical volumes of saline in a similar regimen.

In the postoperative period, clinical patterns of apathy, bristling hair, diarrhea, abdominal distension, and wound complications, such as hematoma and signs of surgical site infection, were assessed.

A second operation was performed on the day previously scheduled for each subgroup. After exposure of the abdominal cavity, signs of peritonitis, abscess, obstruction or anastomotic dehiscence were investigated. Intra-abdominal adhesions were quantitatively scored according to the adhesion scoring system defined by Nair et al. ${ }^{7}$ :

\section{0 - Complete absence of adhesions;}


1 - Single band of adhesion, between viscera, or from one viscus to abdominal wall;

2 - Two bands, either between viscera or from viscera to abdominal wall;

3 - More than two bands, between viscera, or viscera to abdominal wall, or whole of intestines forming a mass without being adherent to abdominal wall;

4 - Viscera directly adherent to abdominal wall, irrespective of number and extent of adhesive bands.

A 4-cm long colon segment, with the anastomosis located in its central part, was removed along with the structures adhering to it. Subsequently, the type of structures adhering to the anastomosis was analyzed. The extent of adhesions present was determined as the percentage of anastomosis covered with adhesions.

The specimen was cut open on the antimesenteric border and divided into three longitudinal segments. The central segment was subjected to tensile strength testing using a VersaTest test stand (Mecmesin VersaTest, United Kingdom) fitted with a digital force gauge (Mecmesin AFG 2500N, United Kingdom). A rectangular tissue sample was fixed at its two ends to the test apparatus by the upper fixing clamp of the force gauge and the lower clamp of the VersaTest, with the anastomotic region equidistant and parallel to the clamps. The tensile test was performed at a speed of $30 \mathrm{~mm} /$ $\min ^{8}$. Tensile strength was measured in Newton $(\mathrm{N})$.

The right lateral segment underwent histopathological analysis and analysis of collagen content. For histopathological analysis, the specimens were fixed in formalin and stained with hematoxylin and eosin. An experienced pathologist, blind to which subgroup the specimens belonged, examined the slides by light microscopy. The following parameters were assessed: congestion, edema, hemorrhage, ulceration, necrosis, mononuclear and polymorphonuclear infiltration, neovascularization, granulation, fibrosis, and fibroblasts (extent, arrangement, and maturity). Each of these parameters was graded as absent (0), mild (1), moderate (2), marked (3), or intense (4).

Quantitative analysis of collagen was performed only in animals euthanized on postoperative seventh day. The slides that more significantly represented all subgroups were selected. In picrosirius-stained sections, the perianastomotic area was analyzed by polarized light microscopy ${ }^{9}$. The total field area was examined using a microscope with a 10x objective, and the material was analyzed by an observer blind to which group the specimens belonged. Images were acquired using a 5.0 mega pixel Moticam 2500 digital camera, coupled to an Olympus CX41 light microscope. All images were analyzed using ImageJ (Wayne
Rasband, Research Services Branch, National Institute of Mental Health, Bethesda, Maryland, USA).

The left lateral segment was used to measure hydroxyproline concentration according to the technique described by Stegemann and Stalder ${ }^{10}$ and modified by Medugorac ${ }^{11}$.

Data were analyzed using the Statistical Package for the Social Sciences $\left(\right.$ SPSS $^{\circledR}$ ) version 18.0. The Mann-Whitney test was used to analyze tensile strength, hydroxyproline concentration, and collagen content. Fisher's exact test was used to evaluate clinical parameters, extent of adhesions, and histological data. The level of significance was set at $\mathrm{p}<0.05$.

\section{Results}

There were no deaths among animals euthanized on postoperative third day. There was one death in each subgroup of animals scheduled for euthanasia seven days after surgery, none of them due to complications related to anastomosis. The animals' clinical course was similar across subgroups.

On third day, an anastomotic dehiscence blocked by omentum and adjacent organs occurred in the bromopride-treated subgroup, and free dehiscence, with presence of feces in the abdominal cavity, occurred in the control subgroup. On seventh day, each subgroup showed one case of blocked anastomotic dehiscence.

Bromopride-treated animals had adhesion scores similar to those of controls both on third $(\mathrm{p}=0.77)$ and seventh days $(\mathrm{p}=1.00)$ postoperatively (Table 1$)$.

TABLE 1 - Extent of intra-abdominal adhesions after intraoperative evaluation of animals treated with either bromopride or saline.

\begin{tabular}{ccccc}
\hline & \multicolumn{4}{c}{ Number of animals } \\
\cline { 2 - 5 } Adhesion score* & $\begin{array}{c}\text { Postoperative } \\
\text { third day }(\mathrm{p}=0.77)\end{array}$ & $\begin{array}{c}\text { Postoperative } \\
\text { seventh day }(\mathrm{p}=1.00)\end{array}$ \\
\hline & Bromopride & Saline & Bromopride & Saline \\
\cline { 2 - 5 } Two bands & 3 & 1 & 0 & 0 \\
Three or more bands & 6 & 8 & 8 & 8 \\
$\begin{array}{c}\text { Directly adherent to } \\
\text { abdominal wall }\end{array}$ & 1 & 1 & 1 & 1 \\
\hline
\end{tabular}

* Adhesion scoring system defined by Nair et al. ${ }^{7}$ 
The percentage of anastomosis covered with adhesions was also similar across groups both on third $(\mathrm{p}=0.58)$ and seventh days $(\mathrm{p}=0.77)$ postoperatively (Table 2$)$.

TABLE 2 - Percentage of anastomosis covered with adhesions in animals treated with either bromopride or saline.

\begin{tabular}{ccccc}
\hline \multirow{2}{*}{$\begin{array}{c}\text { \% of anastomosis } \\
\text { covered } \\
\text { with adhesions }\end{array}$} & $\begin{array}{c}\text { Number of animals } \\
(\mathrm{p}=0.58)\end{array}$ & $\begin{array}{c}\text { Postoperative seventh } \\
\text { day }(\mathrm{p}=0.77)\end{array}$ \\
\cline { 2 - 5 } & $\begin{array}{c}\text { Bromopride } \\
\text { Up to } 24 \%\end{array}$ & Saline & Bromopride & Saline \\
\cline { 2 - 5 } 25 to $49 \%$ & 0 & 2 & 0 & 0 \\
50 to $74 \%$ & 1 & 1 & 1 & 0 \\
74 to $99 \%$ & 3 & 3 & 1 & 3 \\
$100 \%$ & 4 & 4 & 7 & 5 \\
\hline
\end{tabular}

Tensile strength of anastomoses was lower in animals in group E3 than in group C3, with a statistically significant difference $(p=0.02)$ (Figure 2). There was no statistical difference in tensile strength between groups on seventh day $(p=0.79)$ (Figure 3$)$.

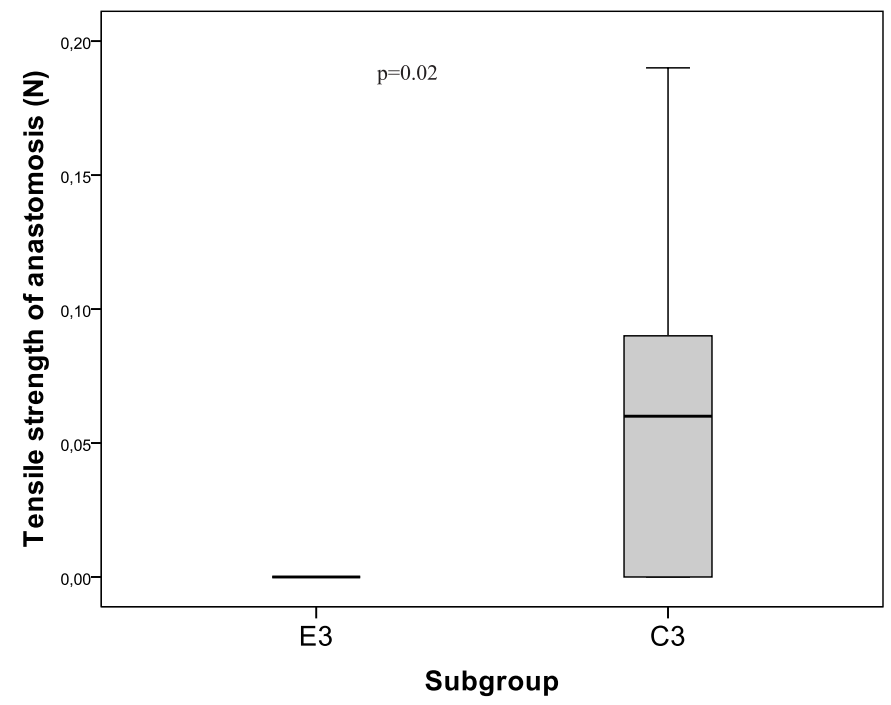

FIGURE 2 - Median and range values of tensile strength, on postoperative third day, in animals treated with either bromopride (E3) or saline (C3).

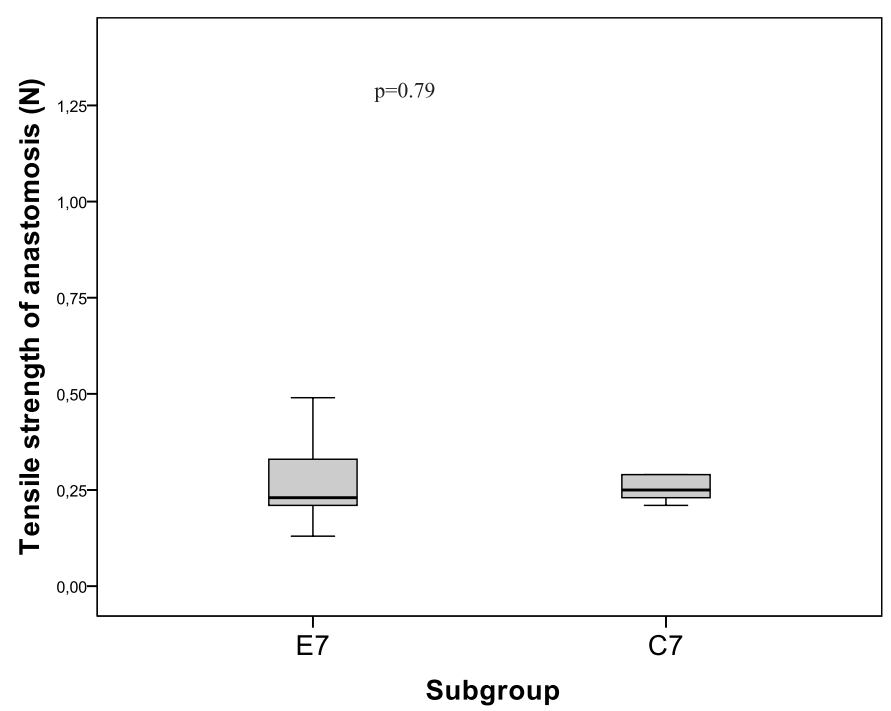

FIGURE 3 - Median and range values of tensile strength, on postoperative seventh day, in animals treated with either bromopride (E7) or saline (C7).

On third day, bromopride-treated animals showed a greater reduction in hydroxyproline concentration than controls $(p=0.04)$ (Figure 4). There was no difference between groups on seventh day $(\mathrm{p}=0.73$ ) (Figure 5). Collagen content on seventh day was also similar across subgroups $(p=0.41)$.

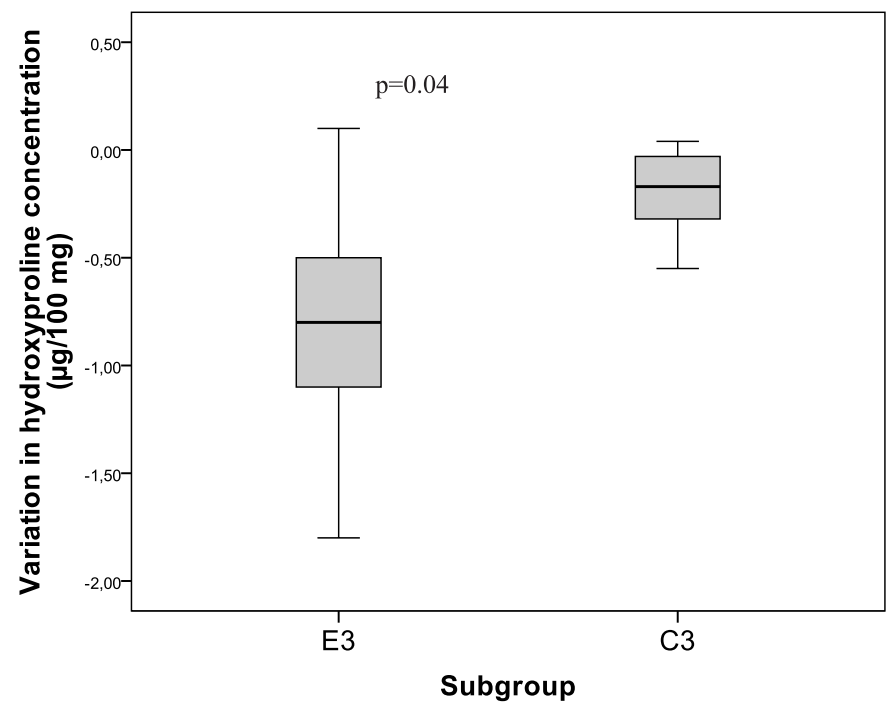

FIGURE 4 - Median and range values of variation in hydroxyproline concentration, on postoperative third day, in animals treated with either bromopride (E3) or saline (C3). 


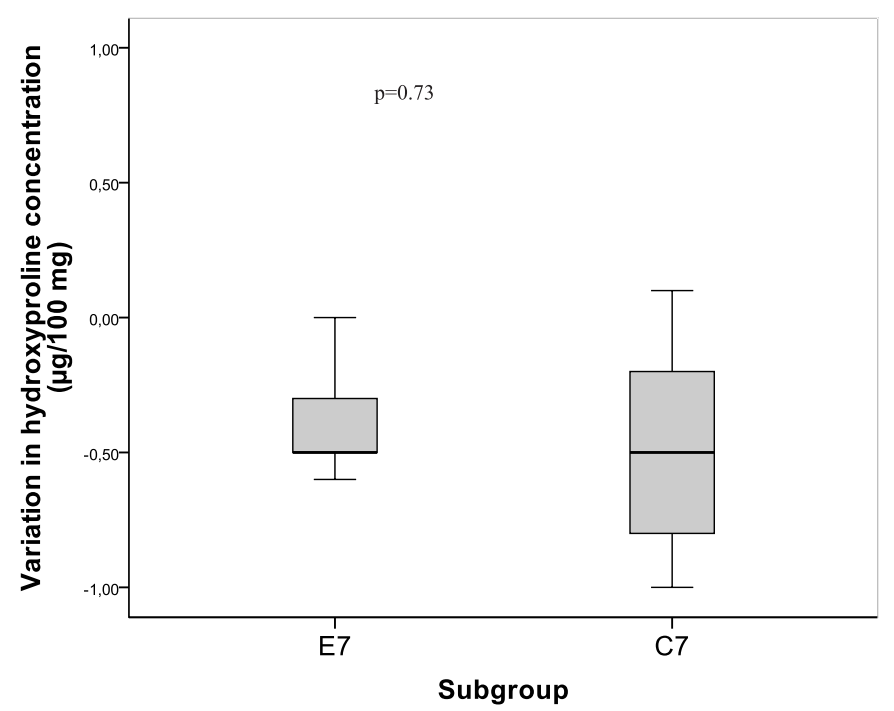

FIGURE 5 - Median and range values of variation in hydroxyproline concentration, on postoperative seventh day, in animals treated with either bromopride (E7) or saline (C7).

On postoperative third day, control animals showed a higher number of bacterial colonies in the anastomotic region than bromopride-treated animals $(\mathrm{p}=0.02)$. On seventh day, bromopridetreated rats showed a higher abscess rate in the anastomotic region than controls $(\mathrm{p}=0.01)$. There was no difference between subgroups in the remaining histopathological parameters.

\section{Discussion}

The colon is the region of the gastrointestinal tract most vulnerable to anastomotic dehiscence ${ }^{12}$. The occurrence of dehiscence is particularly high when suture is performed in the distal colon due to associated fecal loading and technical difficulty $^{13}$. High mortality and severe morbidity associated with dehiscence support the need for further evaluation of methods aiming to reduce its incidence ${ }^{14}$ and the deleterious effects of drugs on wound healing.

Bromopride is a prokinetic agent used in the treatment of postoperative gastroesophageal reflux, nausea, vomiting, and gastrointestinal motility disorders. This is a substituted benzamide drug, such as metoclopramide, and its main action involves the blockade of D2 dopamine receptors in the central nervous system (CNS) and gastrointestinal tract.

In previous studies, we evaluated separately the effects of abdominal sepsis ${ }^{15}$ and administration of bromopride ${ }^{5}$ on the healing of left colonic anastomoses in rats. CLP-induced abdominal sepsis increased the number of intra-abdominal adhesions on postoperative third and seventh days, caused a reduction in tensile strength of anastomoses on third day, with subsequent increase on seventh day, and produced no changes in hydroxyproline concentration or collagen content in the anastomotic region ${ }^{15}$. Treatment with bromopride in the absence of abdominal sepsis produced no changes in adhesion formation within the abdominal cavity or in the anastomosis and caused a reduction in tensile strength of anastomoses on third day, but not on seventh day. In addition, there was no difference in the variation of hydroxyproline concentration in the two experimental periods ${ }^{5}$.

In the present study, we analyzed the joint action of these two factors and confirmed the deleterious effect of bromopride on colonic anastomosis healing, reducing not only tensile strength, but also hydroxyproline concentration three days after surgery. Again, there was no difference between subgroups on postoperative seventh day.

There is no consensus in the literature regarding the mechanism of action of prokinetic agents on the healing of anastomoses or whether such action is due to changes in adhesion formation. García-Olmo et al. ${ }^{16}$ evaluated the effects of pharmacological manipulation of gastrointestinal motility on the resistance of colonic anastomoses and concluded that treatment with metoclopramide was associated with fewer adhesions to the anastomosis and a significant decrease in anastomotic resistance four days after surgery. In another study ${ }^{17}$, metoclopramidetreated animals showed adhesion formation within the abdominal cavity and in the anastomosis similar to that of animals receiving saline three and seven days after surgery. Likewise, tensile strength of anastomoses was similar across subgroups, but hydroxyproline concentration on postoperative third day was higher in metoclopramide-treated animals than in controls. Springall and Spitz ${ }^{18}$ investigated the action of cisapride, another prokinetic agent, on the healing of anastomoses in rats seven days after surgery. Drug administration was associated with a reduced number of adhesions, but with no effects on anastomotic resistance.

In this study, treatment with bromopride in the presence of CLP-induced abdominal sepsis was detrimental in the early stages of healing, with no changes in adhesion formation. Thus, we can infer that the effect of prokinetic drugs on the healing of left colonic anastomoses in rats cannot be attributed to changes in adhesion formation in the anastomosis, suggesting that other mechanisms may be involved.

No differences were found between subgroups regarding collagen content in the tissue. Collagen is the main extracellular matrix protein and a major component of the final scar. In the gastrointestinal tract, collagen is found mainly in the submucosal layer ${ }^{19}$. Collagen is important at all stages of wound healing and is 
critical to the overall strength and integrity of the tissue. However, the final anastomotic strength is not always related to the absolute concentration of collagen, the structure and arrangement of the collagen matrix may be more important $\mathrm{t}^{20}$.

\section{Conclusion}

In the presence of abdominal sepsis, the administration of bromopride was associated with decreased tensile strength and hydroxyproline concentration in left colonic anastomoses in rats three days after surgery.

\section{References}

1. Thornton FJ, Barbul A. Healing in the gastrointestinal tract. Surg Clin North Am. 1997;77(3):549-73.

2. de Sousa JB, Soares EG, Aprilli F. Effects of diclofenac sodium on intestinal anastomotic healing. Experimental study on the small intestine of rabbits. Dis Colon Rectum. 1991;34(7):613-7.

3. de Oliveira PG, Soares EG, Aprilli F. Influence of misoprostol, a synthetic prostaglandin E1 analog, on the healing of colonic anastomoses in rats. Dis Colon Rectum. 1994;37(7):660-3.

4. Ozen IO, Ekingen G, Taslipinar MY, Bukan N, Demirogullari B, Karabulut R, et al. Effect of melatonin on healing of colonic anastomosis in a rat model of peritonitis. Eur Surg Res. 2007;39(2):122-7.

5. Silva SMFV, Carneiro FP, Feres O, Oliveira PG, Sousa JB Effects of bromopride in the anastomoses healing of the left colon of rats. Rev Col Bras Cir. 2011;38(6)249-34.

6. Rittirsch D, Huber-Lang MS, Flierl MA, Ward PA. Immunodesign of experimental sepsis by cecal ligation and puncture. Nat Protoc. 2009;4(1):31-6.

7. Nair SK, Bhat IK, Aurora AL. Role of proteolytic enzyme in the prevention of postoperative intraperitoneal adhesions. Arch Surg. 1974;108(6):849-53.

8. Tognini JRF, Fagundes DJ, Novo NF, Juliano Y. Biomechanical and morphological study in rats' abdominal wall healing under meloxicam action. Acta Cir Bras. 2000;15(3):146-55.

9. Junqueira LC, Bignolas G, Brentani RR. Picrosirius staining plus polarization microscopy, a specific method for collagen detection in tissue sections. Histochem J. 1979;11(4):447-55.

10. Stegemann H, Stalder K. Determination of hydroxyproline. Clin Chim Acta. 1967;18(2):267-73.

11. Medugorac I. Collagen content in different areas of normal and hypertrophied rat myocardium. Cardiovasc Res. 1980;14(9):551-4.

12. Yarimkaya A, Apaydin B, Unal E, Karabicak I, Aydogan F, Uslu E, Erginoz E, Artis T, Eyuboglu E. Effects of recombinant human growth hormone and nandrolone phenylpropionate on the healing of ischemic colon anastomosis in rats. Dis Colon Rectum. 2003;46(12):1690-7.

13. Jiborn $\mathrm{H}$, Ahonen J, Zederfeldt B. Healing of experimental colonic anastomoses. III. Collagen metabolism in the colon after left colon resection. Am J Surg. 1980;139(3):398-405.

14. Hoeppner J, Wassmuth B, Marjanovic G, Timme S, Hopt UT, Keck T. Anastomotic sealing by extracellular matrices (ECM) improves healing of colonic anastomoses in the critical early phase. J Gastrointest Surg. 2010;14(6):977-86.

15. Marques e Silva S, de Oliveira MV, Brandao AM, Carneiro FP, Ferreira VM, Parra RS, Feres O, de Sousa JB. Study on adhesion formation and the healing of colon anastomosis in rats with induced peritoneal sepsis. Acta Cir Bras. 2011;26 Suppl 2:100-5.

16. Garcia-Olmo D, Paya J, Lucas FJ, Garcia-Olmo DC. The effects of the pharmacological manipulation of postoperative intestinal motility on colonic anastomoses. An experimental study in a rat model. Int J Colorectal Dis. 1997;12(2):73-7.

17. Silva SM, Ferreira VM, Feres O, Oliveira PG, Sousa JB. Does metoclopramide impair anastomotic healing of the left colon of rats? Acta Cir Bras. 2011;26(4):297-302.

18. Springall RG, Spitz L. Prevention of post-operative adhesions using a gastrointestinal prokinetic agent. J Pediatr Surg. 1989;24(6):5303.

19. Lord MG, Valies P, Broughton AC. A morphologic study of the submucosa of the large intestine. Surg Gynecol Obstet. 1977; 145(1):55-60.

20. Aydin C, Aytekin FO, Tekin K, Kabay B, Yenisey C, Kocbil G, Ozden A. Effect of temporary abdominal closure on colonic anastomosis and postoperative adhesions in experimental secondary peritonitis. World J Surg. 2006;30(4):612-9.

\section{Correspondence:}

Silvana Marques e Silva

SQS 405 Bloco B/205

70239-020 Brasília - DF Brasil

Tel.: (55 61)9296-1133

silvismarques@yahoo.com.br

Received: January 24, 2012

Review: March 20, 2012

Accepted: April 25, 2012

Conflict of interest: none

Financial source: none

${ }^{1}$ Research performed at Laboratory of Experimental Surgery, Medical School, University of Brasília (UnB), Brazil. 